\title{
Comments on the implications of new radiocarbon dates from the Holsteinsborg region, central West Greenland
}

\section{Michael Kelly}

New radiocarbon dates from the Holsteinsborg region, from the coastal area between Amerdloq fjord and Nordre Strømfjord west of longitude $52^{\circ} \mathrm{W}$, add to the ${ }^{14} \mathrm{C}$ data already published (Weidick, 1972a, 1972b, 1973); Kelly, 1973; Laursen in Weidick, 1972b, 1974), making a total of 51 dates related to sea level and marine faunal histories, including one from just east of the defined area.

\section{Emergence history}

The ${ }^{14} \mathrm{C}$ data relating to past sea level changes are shown in fig. 13 and the location of the samples in fig. 12. The area is orientated parallel to the present ice margin and so far as can be determined emergence has been fairly uniform throughout the area, beginning around $9500 \pm 500 \mathrm{~B}$. P. Although some heterogeneity in isostatic response would be expected in this $4000 \mathrm{~km}^{2}$ area the majority of the data, and in particular most of the critical values, come from the Kangârssuk-Holsteinsborg sector, within a $10 \mathrm{~km}$ radius circle. This represents the densest concentration of such data in coastal West Greenland and theoretically should provide the best opportunity for obtaining an accurate emergence curve.

The vast majority of the dates are from marine shells. They are all based on the inner shell fraction and are plotted with the standard $1 \sigma$ laboratory error. All dates given are un-normalised and no $\delta^{13} \mathrm{C}$ values are available. However since the shell faunas indicate that the marine environment was similar to the present at least as early as $9090 \mathrm{~B}$. P., it is assumed provisionally that, as now, the carbon fractionation and apparent seawater age errors almost cancel out. Krogh \& Tauber (1974) have shown that the residual error is less than \pm 2 per cent on 4 samples of modern, pre-bomb shells from West Greenland. These dates nominally represent the maximum age of a sea level at the field elevation of the sample, which is plotted in fig. 13, relative to modern mean sea level (or at least the Fucus-Balanus line). Although shells in beach ridges, which comprise about a quarter of the shell dates, are likely to have been deposited above their contemporaneous mean sea level the difference cannot be quantified and no account is taken of it in the diagram. Where, however, there is a clear indication that the minimum sea level was above the sample elevation this is shown by a vertical bar e.g. where there is a given thickness of marine sediments stratigraphically above the sample etc.

The other main category is terrestrial organic deposits - peats and lake gyttjas. The gyttja dates, for which $\delta^{13} \mathrm{C}$ values are available, refer to the time of regression of the sea from the level of the lake threshold, determined from the lithological evidence in the sediment cores. They nominally represent minimum estimates of the age of this event because of delays in the development of organic sedimentation after isolation and the need to include younger layers in the sediment interval analysed. This error is particularly significant in the case of I-10288 (7, fig. 13) for which the dated thickness is $7.5 \mathrm{~cm}$, because of technical sampling problems, compared with $1.5 \mathrm{~cm}$ for $\mathrm{I}-10287$ (5, fig. 13). Two other dates are from the basal 


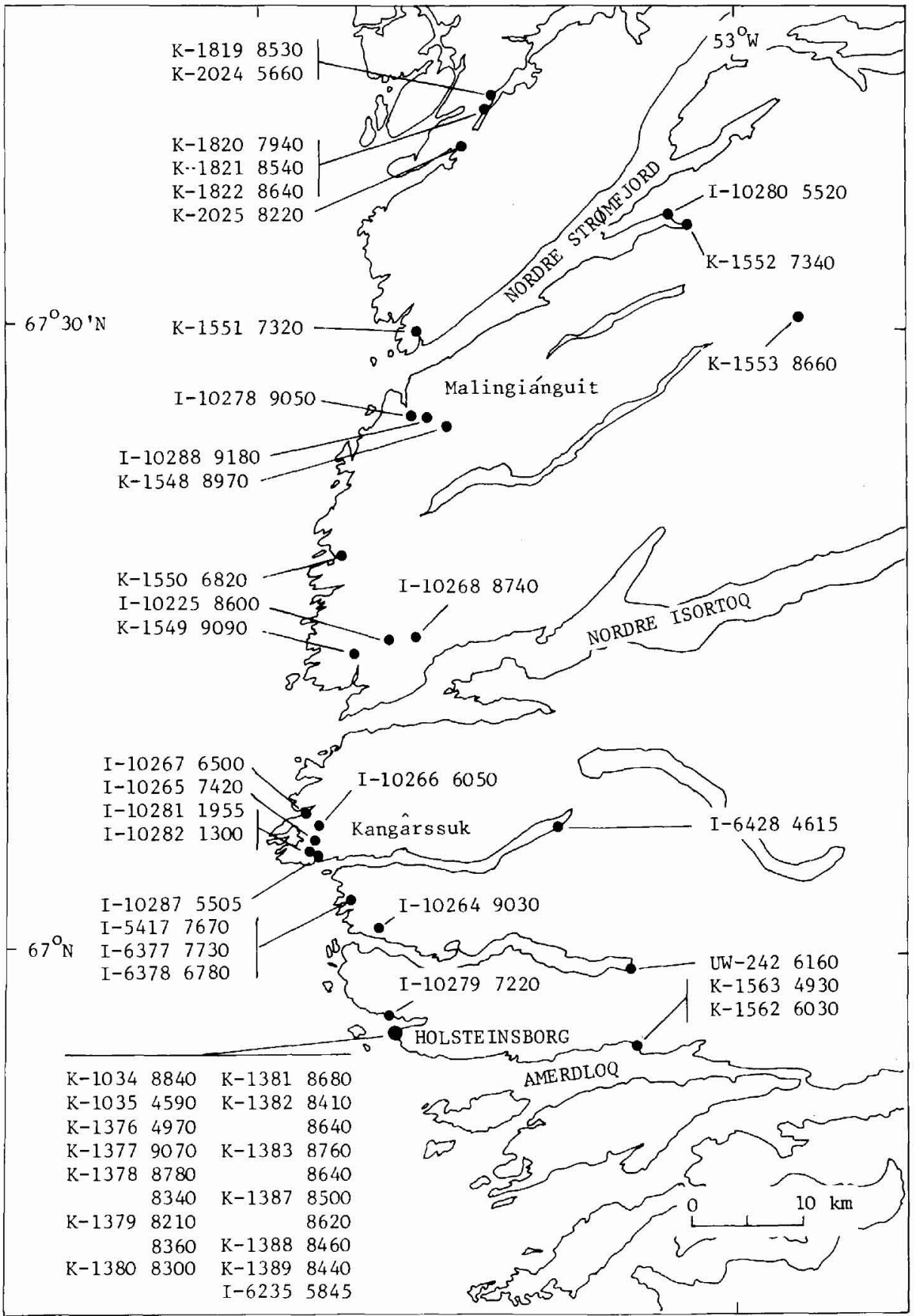

Fig. 12. Localities of ${ }^{14} \mathrm{C}$ dated sites. 


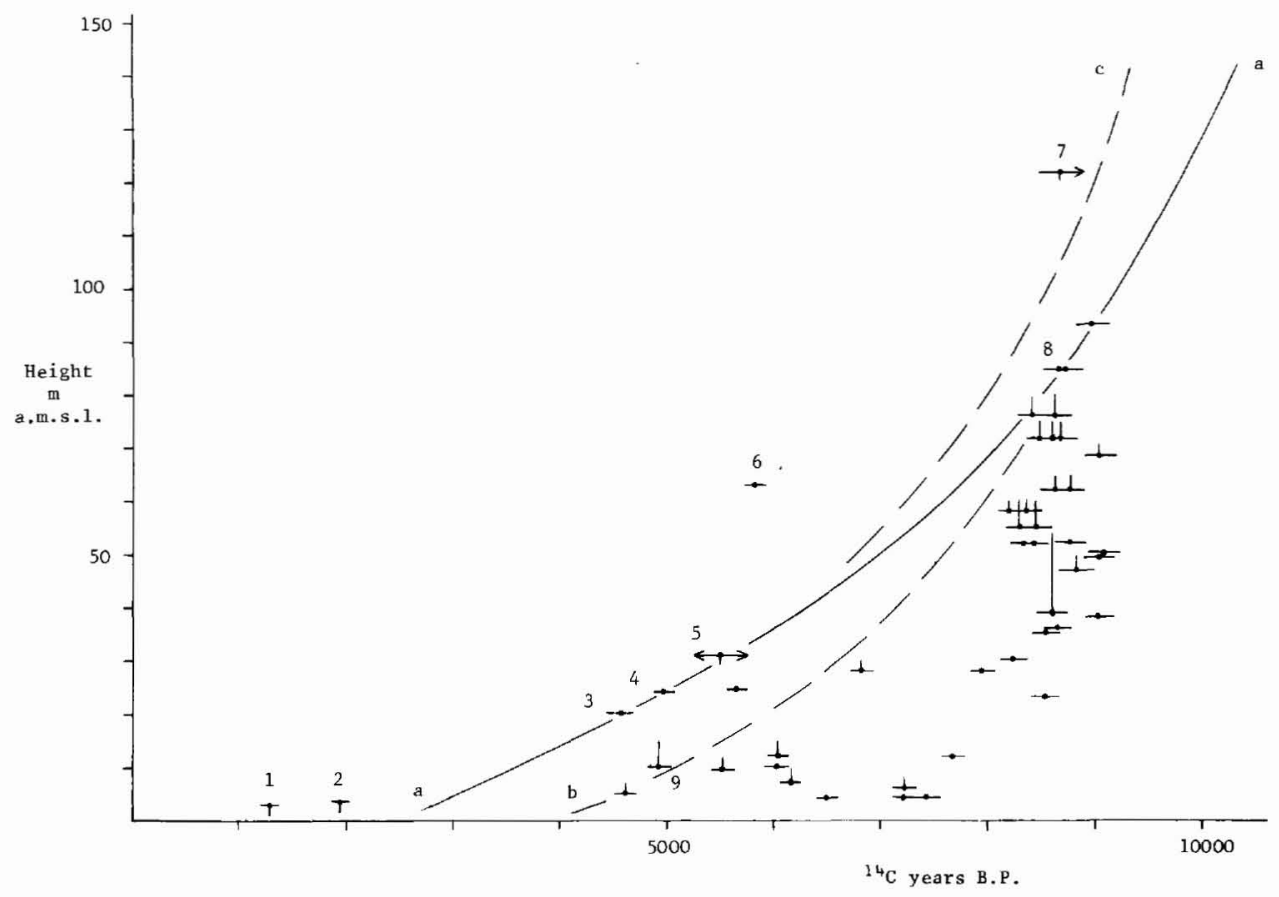

Fig. 13. Emergence curve and alternative emergence curves for the Holsteinsborg coastal region (see text for explanation of symbols and sources of data).

layers of in situ peat deposits at Kangârssuk (1 \& 2, fig. 13). For these four samples the critical sea level is high tide and a vertical bar equal to half the tidal amplitude is shown for these samples in fig. 13, below which the contemporaneous mean sea level must lie. The measured spring tide value at Kangârssuk of $2.3 \mathrm{~m}$ is used. A further date on terrestrial organic material (K-1563: 9, fig. 13) is apparently from reworked material in deltaic sediments (Weidick, 1972a) but it is not clear whether it was deposited below or above sea level.

The field altitudes of the two lakes and of the Kangârssuk peats were determined by theodolite and of the remainning samples by a variety of means - hand level, Paulin aneroid altimeter and theodolite. No account of the errors in these determinations is taken in fig. 13. The height of $\mathrm{K}-1553$ (8, fig. 13), which is from just east of $52^{\circ} \mathrm{W}$, was originally based on a spot height on the 1:250 000 Geodetic Institute map (Kelly, 1973) and was remeasured in 1978 by altimeter as $85 \pm 5 \mathrm{~m}$. Since the spot heights on this map sheet have been found to be very inaccurate the original field altitudes of Laursen (1950) are used for his dates, rather than the revisions based on map sheet spot heights suggested in Weidick (1972b). Two other dates (I-6377 \& I-6378) are excluded because of uncertainty about their field altitude.

An emergence curve showing the net movement of sea level due to combined eustatic and isostatic effects can be drawn from the data of fig. 13. Weidick (1976) has published an emergence curve for the town of Holsteinsborg itself using about half this data, but excluding the shell dates at 4590 and 4970 B. P. for 20 and $24 \mathrm{~m}$ sample heights (K-1035 \& 
K-1376: $3 \& 4$, fig. 13), which he considered to be anomalously young. This he tentatively postulated was due to surges carrying young material to levels considerably above their sea level. Theoretically an apparently young date could also be due to contamination by young carbon due to isotopic exchange, precipitation of secondary carbonate or errors in sampling or laboratory analysis. The last two sources are unlikely causes since the material was dated in two separate batches from two different collections. Nor is there any evidence to suggest that either of the first two operate to any abnormal degree.

In contrast the date for the minimum age of the isolation of the $31 \mathrm{~m}$ lake at Kangârssuk at 5505 B.P. (I-10287: 5, fig. 13) supports the validity of K-1035 and K-1376. Whilst the normal limitations of gyttja dates on regression horizons mentioned above mean that the date is a minimum estimate there are other factors operating here, one of which could counterbalance this. The gyttja has a $\delta^{13} \mathrm{C}$ value of $-16.3 \%$; a content of relatively heavy carbon which could be due to fractionation during metabolic and diagenetic processes, or due to contamination of the lake water or sediment by old carbonate, one possible source of this being the shell bearing marine sediments known to underlie the gyttja. In the former case fractionation means that the quoted date is 140 years too young, and in the latter that the date is too old by an unknown amount.

In fig. 13 two alternative emergence curves $(\mathrm{a} \& \mathrm{~b})$ are presented for the younger period, including and excluding the three data points discussed above, with the former being the preferred case. A degree of uncertainty exists also about the position of the upper part of the curve and a range of positions (a to c) satisfy the $122 \mathrm{~m}$ lake regression date ( 7 , fig. 13 from Malingiánguit and the high level shell dates from there and Holsteinsborg (K-1548, K-1553, $\mathrm{K}-1382$ ). All these represent the emergence by a smooth curve, which the more detailed work from the Canadian Arctic suggests is a valid first approximation (Blake, 1975).

The zone within which it is suggested the emergence curve should lie is compared in fig. 14 with other curves for central West Greenland. It has the same form as Weidick's (1976) curve for Holsteinsborg, based on a limited version of the same data base, but with the preferred curve giving slower rates of emergence. This is also the case with a curve for the Nordre Strømfjord coastal region based on yet more limited data (Kelly, 1973). It is also very close in form to the set of alternative curves drawn for south-east Disko Bugt (Donner \& Jungner, 1975) and Disko (Donner, 1978). However an emergence curve for the middle Søndre Strømfjord area (Ten Brink, 1975) is much steeper. Although this curve comes from an area deglaciated somewhat later than Holsteinsborg, its steepness appears to be an artifact of the way in which the data have been assigned from two overlapping areas to the emergence curves drawn for middle and inner Søndre Strømfjord.

A significant feature is the evidence that sea level has been at or below present sea level since at least 2000 B.P. This agrees with Weidick's (1976) conclusion that uplift in West Greenland ended some time ago, although he puts this at 4000-5000 B.P. These features and the evidence of subsidence of archaeological and other sites continuing into historic times, quoted in Weidick (1976), are considered to represent the Neoglacial Transgression caused by the Neoglacial expansion of the Greenland Ice Sheet. The mechanism suggested here for this is the outward migration of the elastically depressed zone around the margin of the advancing ice sheet. According to the model of Walcott (1969), which would appear to 


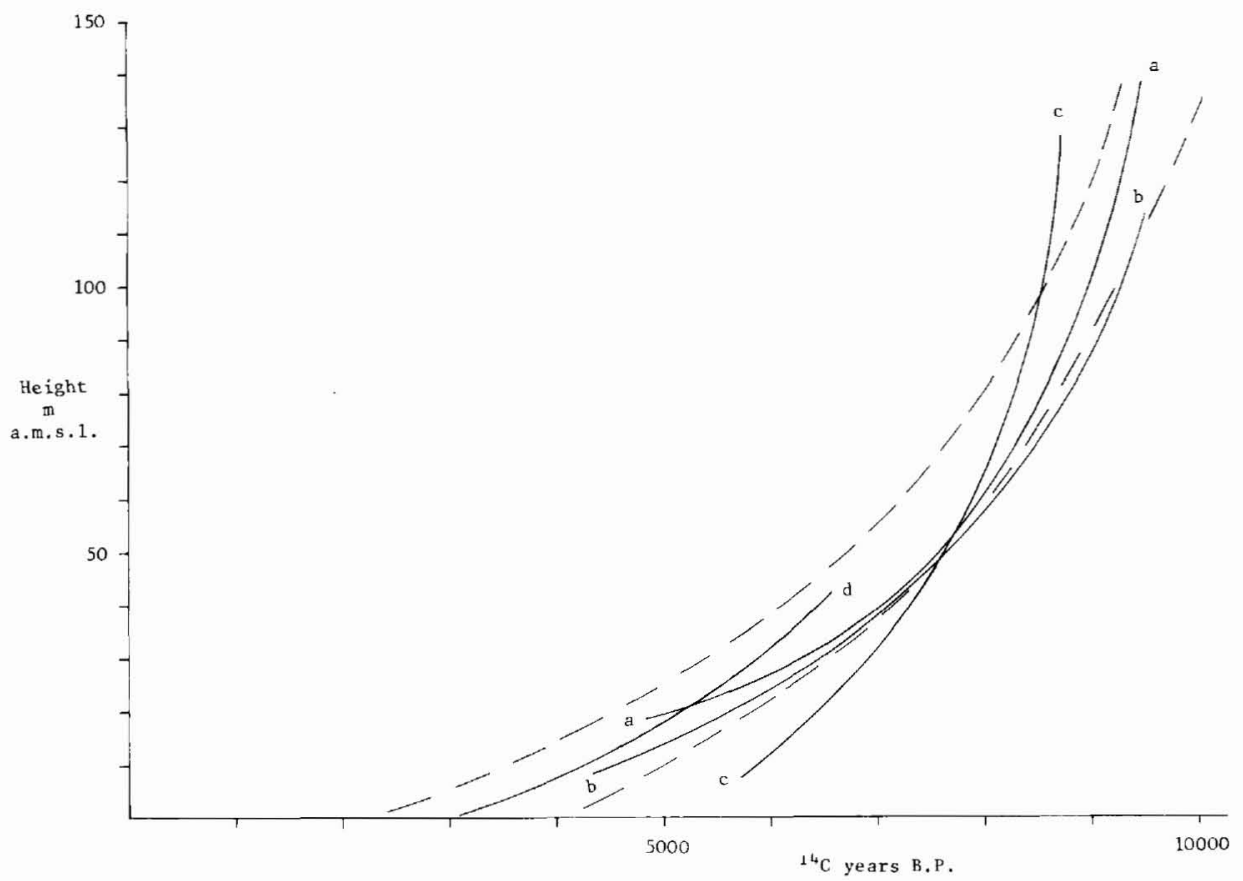

Fig. 14. Comparison of published emergence curves for central West Greenland (dashed lines: limits of curves for Holsteinsborg region shown in fig. 2; a: Holsteinsborg town (Weidick, 1976); b: outer Nordre Strømfjord (Kelly, 1973); c: middle Søndre Strømfjord (Ten Brink, 1975); d: Disko (Donner, 1978), (lower part of curve only).

be a conservative one for the Greenland Ice Sheet, a point at the distance of Holsteinsborg from the ice margin would be depressed $c .10 \mathrm{~m}$ by a $15 \mathrm{~km}$ advance - a figure which is by no means improbable for the Neoglacial Readvance (e.g. Kelly, 1975).

It is clear from fig. 13 that the vast majority of dated shell samples lie below their contemporaneous sea levels. These may represent various categories of in situ or contemporaneously reworked death assemblages (Kelly, 1973), deposited at some depth below sea level. Alternatively they are shells from older shell bearing sediments reworked by wave action as sea level fell, giving deposits, especially in raised beaches with anomalously old faunas. For example it can be seen that faunas from $8000-9000$ B.P. have been continuously reworked as sea level fell, to be incorporated in beach ridges and littoral sediments from 85 to $50 \mathrm{~m}$ above present sea level.

A dated whale cranium (6, fig. 13) is also clearly out of context and the sample is presumed to have been contaminated (Weidick, personal communication).

\section{Faunal history}

Table 2 gives the faunal composition of the horizons dated by the new ${ }^{14} \mathrm{C}$ determinations in the Holsteinsborg region. It supplements information on the faunal history of the area 
Table 2. Faunal composition of ${ }^{14} \mathrm{C}$ dated horizons

\begin{tabular}{|c|c|c|c|c|c|c|c|c|c|}
\hline GGU No. & 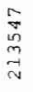 & $\begin{array}{l}0 \\
\stackrel{0}{0} \\
\stackrel{2}{m} \\
\stackrel{-1}{v}\end{array}$ & $\begin{array}{l}\vec{H} \\
\vec{n} \\
\vec{m} \\
\vec{v}\end{array}$ & $\begin{array}{l}\underset{N}{n} \\
\stackrel{n}{\rightarrow} \\
\vec{v}\end{array}$ & $\begin{array}{l}q \\
\vec{n} \\
\stackrel{n}{n} \\
\vec{v}\end{array}$ & $\begin{array}{l}\stackrel{v}{f} \\
\text { in } \\
\text { ने } \\
\vec{v}\end{array}$ & $\begin{array}{l}\tilde{r} \\
\sigma \\
\text { เn } \\
\stackrel{\sim}{\sim}\end{array}$ & $\begin{array}{l}\vec{m} \\
\hat{m} \\
\vec{\omega} \\
\vec{v}\end{array}$ & $\begin{array}{l}\stackrel{0}{\sigma} \\
\stackrel{\sigma}{\sim} \\
\vec{\sim}\end{array}$ \\
\hline Lab. No. & $\begin{array}{l}\sqrt[1]{2} \\
\text { v } \\
0 \\
\stackrel{1}{1} \\
\stackrel{-1}{1}\end{array}$ &  & $\begin{array}{l}0 \\
0 \\
N \\
0 \\
\overrightarrow{1} \\
1 \\
1\end{array}$ & $\begin{array}{l}0 \\
ٌ \\
ٌ \\
0 \\
-1 \\
1 \\
-1\end{array}$ & 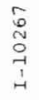 & $\begin{array}{l}\infty \\
0 \\
0 \\
\sim \\
0 \\
1 \\
11\end{array}$ & \begin{tabular}{l}
$\infty$ \\
\multirow{2}{v}{} \\
0 \\
$\frac{1}{1}$
\end{tabular} & $\begin{array}{l}a \\
\stackrel{2}{y} \\
0 \\
\frac{1}{1}\end{array}$ & $\begin{array}{l}0 \\
0 \\
\infty \\
\sim \\
0 \\
\stackrel{1}{1} \\
1 \\
-1\end{array}$ \\
\hline Date yr. B.P. & \begin{tabular}{l}
8 \\
\multirow{7}{*}{} \\
+1 \\
8 \\
0 \\
0 \\
$\infty$
\end{tabular} & 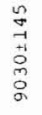 & 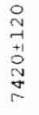 & $\begin{array}{l}0 \\
0 \\
-1 \\
+1 \\
0 \\
\text { in } \\
0 \\
0\end{array}$ & $\begin{array}{l}0 \\
+ \\
7 \\
+1 \\
0 \\
0 \\
0 \\
0\end{array}$ & $\begin{array}{l}\stackrel{P}{J} \\
\stackrel{+1}{+} \\
\stackrel{\sim}{\sim} \\
\underset{\infty}{\infty}\end{array}$ & $\begin{array}{l}0 \\
\text { In } \\
\text { I1 } \\
0 \\
\text { 1n } \\
0 \\
\text { a }\end{array}$ & 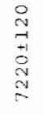 & $\begin{array}{l}n \\
0 \\
-1 \\
+! \\
0 \\
\text { in } \\
\text { in }\end{array}$ \\
\hline \multicolumn{10}{|l|}{ Crustaceae } \\
\hline Balanus balanus & & + & + & + & + & + & + & + & \\
\hline $\begin{array}{l}\text { Balanus hammeri } \\
\text { Brachiopoda }\end{array}$ & & & + & + & & & + & & \\
\hline Hemithyris psittacea & & + & & & & & + & & \\
\hline $\begin{array}{l}\text { Lamellibranchiata } \\
\text { Leda minuta }\end{array}$ & & & & & & & & + & \\
\hline Mytilus edulio & & & * & $*$ & + & & & $\$$ & \\
\hline Chiamys isiandious & + & + & + & + & & + & + & + & \\
\hline Astarte borealis & & & & + & & & & & \\
\hline Astarte montagui & & + & & & + & + & + & & \\
\hline Axinopsis oroiculata & & & & + & + & & & 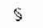 & \\
\hline $\begin{array}{l}\text { Serripes groentandious } \\
\text { Cyprina is iandiod }\end{array}$ & & & + & + & + & & & + & \\
\hline clinocardium ciliatum & + & & & & + & & & & \\
\hline Macoma calcarea & & + & & + & + & + & & + & \\
\hline Hiatella arctica & + & + & + & & + & + & + & 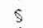 & \\
\hline Mya truncata & $=$ & * & + & + & & * & $*$ & * & it \\
\hline Gast ropoda & & + & + & & & & + & $\S$ & \\
\hline Echinodermata & & + & + & + & + & + & + & + & \\
\hline Bryozoa & & + & & + & + & & + & + & \\
\hline Polychaetes & & + & & + & + & & + & + & \\
\hline Sample type & $\mathrm{a}$ & $b$ & $\mathrm{a}$ & c & $c$ & $\mathrm{a}$ & c & $c$ & b \\
\hline
\end{tabular}

given in Kelly (1973), Laursen (1950) and Weidick (1972a) and confirms certain features of the Holocene faunal development described previously.

Firstly the modern low arctic fauna, for which Mytilus edulis and Chlamys islandicus are key species in these fossil assemblages, was present very early in the Holocene, from the late Preboreal. Chlamys, though not itself dated, is present in dated faunas from 9030 B.P. (I-10264) and 9050 B.P. (I-10278), complementing the earlier records of 9090 B.P. (K-1549) for Chlamys (Kelly, 1973) and 9070 B.P. (K-1377) for Mytilus (Weidick, 1972a).

Secondly, there is additional evidence of the timing of the mid-Holocene warm episode characterised by species extinct today in West Greenland, especially the lamellibranchs Cyprina islandica, Zirphaea crispata, Panomya norvegica and Anomia squammula (Jensen, 1942). A list of directly and indirectly dated occurrences of the first two is given in Table 3 .

The two previous records of Cyprina islandica are two separate collections apparently from the same locality in Itivdleq fjord south of Holsteinsborg which can be indirectly dated to $>6000-7000$ B.P. using the emergence curves. The Eqalunguit locality is therefore only the second known occurrence of the species, and is dated by analysis of Cyprina itself to 6500 B.P. 
Table 3. Dated occurrences of some thermophilous bivalve molluscs

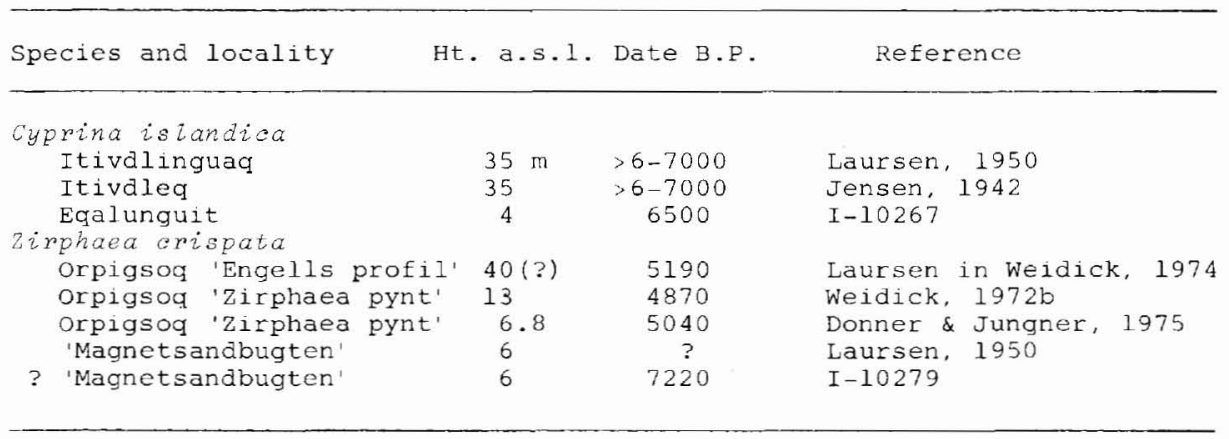

The date of 7220 B.P. (I-10279) on Mya truncata is from the same locality at Holsteinsborg that Laursen (1950) records a single specimen of Zirphaea crispata. No specimens of Zirphaea were found on this occasion and the date is rather old in comparison with the other records.

\section{Conclusion}

It is obvious that the Holocene emergence history of West Greenland has not yet been satisfactorily defined, particularly in its early and late stages, and that the elucidation of these marine shell data is likely to have limited utility.

\section{Acknowledgements}

I am grateful to Erik Olsen and Ian Shaw for support and assistance in the field and to Carolyn Amos for secretarial work.

\section{References}

Blake, W. 1975: Radiocarbon age determinations and postglacial emergence at Cape Storm, southern Ellesmere Island, Arctic Canada. Geogr. Annlr 57, 1-71.

Donner, J. 1978: Holocene history of the west coast of Disko, central West Greenland. Geogr. Annlr 60A, 63-72.

Donner, J. \& Jungner, H. 1975: Radiocarbon dating of shells from marine Holocene deposits in the Disko Bugt area, West Greenland. Boreas 4, 25-45.

Jensen, A. S. 1942: Two new West Greenland localities for deposits from the ice age and the post-glacial warm period. $K$. danske Vidensk. Selsk. Skr. 17, 4, 35 pp.

Kelly, M. 1973: Radiocarbon dated shell samples from Nordre Strømfjord, West Greenland, with comments on models of glacio-isostatic uplift. Rapp. Grønlands geol. Unders. 59, 20 pp.

Kelly, M. 1975: A note on the implications of two radiocarbon dated samples from Qaleragdlit imâ, South Greenland. Bull. geol. Soc. Denmark 24, 21-26.

Krogh, H. \& Tauber, H. 1974: C-14 chronology of Late- and Post-glacial marine deposits in North Jutland. Danm. geol. Unders. Arbog 1973, 93-105. 
Laursen, D. 1950: The stratigraphy of the marine Quaternary deposits in West Greenland. Bull. Grønlands geol. Unders. 2 (also Meddr Grønland 151, 1) 142 pp.

Ten Brink, N. W. 1975: Holocene history of the Greenland Ice Sheet based on radiocarbon-dated moraines in West Greenland. Bull. Grønlands geol. Unders. 113 (also Meddr Grønland 201, 4) 44 pp. Walcott, R. I. 1969: Isostatic response to loading of the crust in Canada. Can. J. Earth Sci. 7, 716-727.

Weidick, A. 1972a: Holocene shore-lines and glacial stages in Greenland - an attempt at correlation. Rapp. Grønlands geol. Unders. 41, 39 pp.

Weidick, A. 1972 b: $C^{14}$ dating of Survey material performed in 1971. Rapp. Grønlands geol. Unders. 45, 58-67.

Weidick, A. 1973: $\mathrm{C}^{14}$ dating of Survey material performed in 1972. Rapp. Grønlands geol. Unders. 55, 66-75.

Weidick, A. 1974: $\mathrm{C}^{14}$ dating of Survey material performed in 1973. Rapp. Grønlands geol. Unders. 66, $42-45$.

Weidick, A. 1976: Glaciation and the Quaternary of Greenland. In Escher, A. \& Watt, W. S. (edit.) Geology of Greenland, 430-460. Copenhagen: Geol. Surv. Greenland.

Department of Environmental Sciences, University of Lancaster, Lancaster LA1 $4 Y Q$, England.

\section{Developments in petroleum exploration offshore West Greenland in 1978}

\section{Gilroy Henderson}

During the winter of 1977-1978 results to date from all work undertaken in the concession areas offshore West Greenland were thoroughly reviewed by the concessionaires. A negative evaluation had already been placed on this area because of the disappointing results from all the wells drilled in 1976 and 1977, in particular the lack of the necessary combination of suitable source rocks and reservoir rocks (Henderson, 1978). After further consideration, companies that had earlier contemplated drilling in 1978 decided against doing so. In the event, the only work undertaken within the concession area was a seismic survey by the Chevron Group in concession 28, amounting to some 341 line kilometres.

By the end of November 1978 notice of intention to relinquish had been given for 10 out of the 13 concessions granted in 1975 (Henderson, 1976) and only three, nos 27 and 28 (Chevron Group) and 32 (Mobil Group) were still retained.

During 1978 Survey staff were engaged in a full evaluation of all geophysical and well data from this part of the West Greenland shelf, firstly in order to be able to advise the Ministry for Greenland on the petroleum potential of this area in the light of developments and secondly with a view to publication of data and interpretations as soon as the periods of confidentiality expire.

The Survey was well supplied through the Ministry for Greenland with data and company 